\author{
JACEK BRDULAK \\ Szkoła Główna Handlowa w Warszawie, Polska - SGH Warsaw School of Economics, Poland \\ EWELINA FLORCZAK \\ Uczelnia Łazarskiego, Warszawa, Polska - Lazarski University, Warsaw, Poland \\ TOMASZ GARDZIŃSKI \\ Uczelnia Łazarskiego, Warszawa, Polska - Lazarski University, Warsaw, Poland
}

\title{
Prospołeczność w gospodarce jako czynnik zmian współczesnej ekonomii
}

\section{Prosociality in the economy as a factor of changes in contemporary economics}

\begin{abstract}
Streszczenie: Artykuł dotyczy problematyki zmian zachodzących we współczesnej ekonomii. Autorzy stawiają tezę, że ekonomia humanizuje się i poszukuje nowego ładu w kreowaniu rozwoju społeczno-gospodarczego. Na początku autorzy określają uwarunkowania współczesnego kapitalizmu i przedstawiają jego cechy w kontekście zjawiska globalizacji. Następnie autorzy wprowadzają zagadnienie kosztów ograniczeń kapitalizmu. Istotą artykułu jest problematyka prospołeczności w gospodarce kapitalistycznej w świetle zmian paradygmatu w ekonomii. Wprowadzanie aspektu prospołeczności jest związane ze zmianą paradygmatu w ekonomii. W tym kontekście przedstawione zostały m.in. przedsiębiorstwo społeczne i społeczna gospodarka rynkowa jako kierunek zmian w postrzeganiu rynku i działalności gospodarczej. Jak wskazują autorzy, wzrost roli prospołeczności w gospodarce osłabi występujące konflikty życia społeczno-gospodarczego, może przyczynić się do redukcji napięć kapitalistycznych stosunków produkcji i - zarazem - do systematycznej redukcji kosztów globalnej gospodarki oraz życia społecznego.
\end{abstract}

\begin{abstract}
The article deals with the issues of changes taking place in modern economics. The authors argue that the economy is humanising and is looking for a new order in creating socio-economic development. First, the authors define the conditions of contemporary capitalism. Its features are presented in the context of the phenomenon of globalisation. Next, the issue of the cost of constraints of capitalism is introduced. The essence of the article is the issue of prosociality in the capitalist economy in the light of paradigm changes in the economy. Introducing the aspect of prosociality is associated with a paradigm shift in economics. In this context, social enterprise and social market economy were presented as a direction of changes in the perception of the market and economic activity. As the authors point out, the increased role of prosociality in the economy will weaken the existing conflicts in social and economic life, may contribute to the reduction of tensions in capitalist production relations and, at the same time, to the systematic reduction of the costs of the global economy and social life.
\end{abstract}

Słowa kluczowe: kapitalizm; paradygmat w ekonomii; przedsiębiorstwo społeczne; społeczna gospodarka rynkowa 
Keywords: capitalism; paradigm in economy; social enterprise; social market economy

Otrzymano: 15 października 2020

Received: 15 October 2020

Zaakceptowano: 13 maja 2021

Accepted: 13 May 2021

Sugerowana cytacja/Suggested citation:

Brdulak, J., Florczak, E., Gardziński, T. (2021). Prospołeczność w gospodarce jako czynnik zmian paradygmatu współczesnej ekonomii. Przedsiębiorczość - Edukacja [Entrepreneurship - Education], 17(1), 153-164. https://doi.org/10.24917/20833296.171.12

\section{Wstęp}

Mamy możliwość, a może także przywilej, obserwacji niezwykle ciekawych, coraz bardziej skutkujących w nie zawsze pozytywny sposób procesów rozwoju życia społeczno-gospodarczego. W wymiarze osobistym, lokalnym, regionalnym, międzynarodowym i ostatecznie - globalnym ludzkość szybko rozwija się ilościowo, ale jednocześnie postęp naukowo-techniczny pozwala nam coraz lepiej komunikować się ze sobą. Rośnie globalna świadomość społeczna i przestrzenna pojawiających się napięć rozwojowych. Życie społeczno-gospodarcze wokół nas staje się coraz bardziej skomplikowane i ciągle przyspiesza. Globalizacja jest coraz bardziej nieograniczonym ruchem: ludzi, kapitału, czynników produkcji, towarów, usług, technologii, informacji, wiedzy i idei (Kuciński, 2015: 453). W wymiarze ekonomicznym zjawisko to jest definiowane jako „proces poszerzenia i pogłębienia się współzależności między krajami i regionami wskutek rosnących przepływów międzynarodowych oraz działalności korporacji transnarodowych, co prowadzi do jakościowo nowych powiązań między firmami, rynkami i gospodarkami” (Liberska, 2002: 20). Wydaje się, że tylko jakiś niewyobrażalny kataklizm mógłby zakłócić te procesy (np. globalny konflikt termonuklearny, katastrofa kosmiczna, pandemia). Biorąc pod uwagę te zagrożenia, autorzy stawiają tezę, że ekonomia humanizuje się i poszukuje nowego ładu w kreowaniu rozwoju społeczno-gospodarczego. Przejawia się to zarówno w specyfice uwarunkowań współczesnego kapitalizmu, jak i w postępujących przejawach prospołeczności w naukach ekonomicznych oraz w praktyce gospodarczej.

\section{Uwarunkowania współczesnego kapitalizmu}

Siłą sprawczą globalizacji procesów społeczno-gospodarczych pozostają kapitalistyczne stosunki produkcji. Jeżeli nawet są na świecie kraje, które deklaratywnie uważają, iż ich gospodarek to nie dotyczy (Korea Płn., Wenezuela, Kuba), to mają one obecnie jedynie charakter względnie izolowanych enklaw społeczno-gospodarczych. W związku z dynamicznie zmieniającą się sytuacją kapitalizm staje przed poważnymi wyzwaniami rozwojowymi, które w najbliższej przyszłości przesądzą o jakości życia ludzkości. Poszukiwanie dróg rozwoju kapitalizmu oraz sposobów jego społecznie akceptowanego rekonfigurowania wywołuje coraz większe zainteresowanie naukowców i praktyków gospodarczych (Brdulak, Florczak, Gardziński, 2019a: 66-87; Brdulak, Florczak, Gardziński, 2019c: 74). Chodzi przy tym o identyfikację najważniejszych zagrożeń rozwojowych i poszukiwanie racjonalnych sposobów przeciwdziałania ich negatywnym skutkom. 
Cechą współczesnego kapitalizmu jest długookresowe utrzymywanie się strukturalnej nadpodaży produkcji. Dotyczy to centrów aktywności gospodarczej w Europie Zachodniej, Ameryce Północnej i na Dalekim Wschodzie, w tym w Japonii, Korei Płd., a także Chin. W globalnej gospodarce wykształciła się kategoria nadwyżki ekonomicznej, która oznacza różnicę między tym, co wytwarza społeczeństwo, a ilością produkcji koniecznej do reprodukcji tegoż społeczeństwa (Wrenn, 2018: 149). Cykl akumulacji napędza wszystkie systemy kapitalistyczne i dzieje się to paradoksalnie przy głębokim zróżnicowaniu warunków egzystencjalnych społeczeństw. W interesie przedsiębiorstw leży nieustanne rozszerzanie produkcji. Kapitał pozwala zarobić, jeżeli jest dobrze wydawany. Nie ma obecnie większych ograniczeń przy zdobywaniu przez przedsiębiorstwa, a szczególnie korporacje transnarodowe, finansowych środków inwestycyjnych. Czynnikami sprzyjającymi inwestycjom są, obok finansjeryzacji życia gospodarczego, także postęp naukowo-techniczny, rozwój technologii, robotyzacja i automatyzacja procesów wytwórczych, ich wirtualizacja redukująca koszt odległości przestrzennej, brak większych barier współpracy międzynarodowej.

Występowanie nadwyżki ekonomicznej prowadzi do strukturalnej nierównowagi między mocami wytwórczymi a granicami konsumpcji. W społeczeństwach bogatych i średnio zamożnych obserwujemy swoiste przesuwanie kapitału z bezpośrednich inwestycji produkcyjnych w sferę usług mających zapewnić zbywalność wytwarzanych produktów (marketing z agresywną reklamą i promocją, obsługa konsumencka, kształtowanie wzorców konsumpcji i in.). Jak podaje współczesna literatura naukowa, nadwyżka ekonomiczna „podważa zarazem podstawowe założenia porządku neoliberalnego, który przyjmuje racjonalne dostosowanie się aktywności gospodarczej do wymogów rynku i kształtujących się na nim cen. Okazuje się, że ani nie jesteśmy tak racjonalni w decyzjach produkcyjno-inwestycyjnych, ani ruch cen nie przebiega bez ingerencji producentów [...]" (Brdulak, Florczak, Gardziński, 2019b: 75). Jeżeli dodać do omawianych faktów opóźnienia i trudności w kosztownym ograniczaniu mocy wytwórczych, to oznacza, że gospodarka kapitalistyczna w skali globalnej boryka się od wielu lat z problemem stagnacji. Wiąże się to $\mathrm{z}$ wysokim stopniem jej monopolizacji, a raczej - oligopolizacji, co dodatkowo utrwala utrzymywanie się dysproporcji rozwojowych globalnej gospodarki (por. Palley, 2012).

Problemy nadwyżki ekonomicznej, marnotrawstwa, stagnacji i utrzymujących się dysproporcji rozwojowych globalnej gospodarki są ściśle związane z innymi narastającymi problemami rozwojowymi świata. Wzrastająca konsumpcja w najzamożniejszych państwach nabiera cech marnotrawczego konsumpcjonizmu. Rozwój produkcji wymaga zasobów, a te są ograniczone i już zaznaczają się dotkliwe ich deficyty (np. brak metali rzadkich, niezbędnych w najnowocześniejszych dziedzinach wytwórczości przemysłowej). Typ zasobowego wzrostu gospodarczego, w którym kraje opierają swoją przewagę konkurencyjną na eksploatacji surowców mineralnych lub rozległych areałów rolnych, przechodzi powoli do historii. Zależy nam na inwestycyjnym i przede wszystkim innowacyjnym wzroście gospodarczym, ale jednocześnie T. Piketty zwraca uwagę na rosnącą rolę w bogatych społeczeństwach tzw. wzrostu dobrobytowego. Polega on na wykorzystywaniu skumulowanego historycznie i pokoleniowo bogactwa (Piketty, 2015: 749), a nie na tworzeniu inwestycyjnym nowych miejsc pracy i szybszego zwiększania produktu krajowego brutto (PKB). Ten typ wzrostu gospodarczego nie należy do najbardziej efektywnych i niestety zbyt często utrwala konsumpcjonistyczny, egoistyczny społecznie model życia. 
Uspołecznienie kosztów ograniczeń kapitalizmu

Przezwyciężanie współczesnych ograniczeń kapitalizmu można ostatecznie sprowadzić do swoistego, wspólnego mianownika, którym pozostaje jakość kapitału ludzkiego. Wyraża się ona w kulturze, a więc zachowaniu ludzkim, świadomości otaczających uwarunkowań, wiedzy, nagromadzonych doświadczeniach, inteligencji - w tym emocjonalnej, przedsiębiorczości, umiejętnościach komunikacyjnych, gotowości do partycypacji w zmianach. Te czynniki i wiele innych umykały przez setki lat uwadze naukowców próbujących zrozumieć rzeczywistość gospodarczą i zamykających ją w modelowych uproszczeniach. Ludzie traktowani byli w procesach wytwórczych i zarządczych jako reprodukująca się siła robocza, stawali się elementem taśmy produkcyjnej, konkurowali z maszynami. Druga połowa ubiegłego wieku przyniosła największe, wprost wstydliwe odkrycie. To człowiek jest hegemonem, to on swoimi decyzjami buduje stosunki rynkowe i nadaje kształt różnym odmianom kapitalizmu. Nie ma żadnych uniwersalnych praw ekonomicznych (Drucker, 1994). Ludzie wypełniają decyzjami lepsze lub gorsze propozycje intelektualne naukowców i czasami udaje się je praktycznie zweryfikować. Najczęściej jednak bywamy zaskakiwani przejawami praktyki społeczno-gospodarczej.

Obecny wiek przynosi potwierdzenie powyższych, rewolucyjnych konstatacji. Obserwujemy humanizację ekonomii. Dokonuje się ona wielopłaszczyznowo. Przedmiotem poważnych analiz staje się sama praca ludzka. W niedalekiej przyszłości prawdopodobnie będziemy inaczej pracować i nie wszystkie zmiany muszą oznaczać redukcję miejsc pracy, robotyzację lub automatyzację procesów wytwórczych, czy też narastanie obaw przed zmianami. Należy sądzić, że zmiany rynków pracy w skali globalnej będą przyspieszać (Dirksen, 2018: 1-6). Głębokie zmiany dokonują się w praktycznej sferze podejmowania decyzji zarządczych. Skoro w życiu społeczno-gospodarczym decyzje są domeną ludzi z ich nieprzewidywalnością, emocjami, kulturowymi wyobrażeniami, to praktyka gospodarcza uwarunkowana jest przede wszystkim czynnikami pozaekonomicznymi, takimi jak: kultura, psychologia, psychologia społeczna, polityka społeczna i gospodarcza, socjologia. Skutki podejmowania decyzji gospodarczych i konkurencyjność związana z ich jakością zmuszają do uwzględniania szeroko rozumianych uwarunkowań humanistycznych, behawioralnych (por. Leśniewski, 2015: 1-256; Miroński, 2013: 1-190).

\section{Prospołeczność w gospodarce kapitalistycznej w świetle zmian współczesnej ekonomii}

Nawiązując do poprzednich rozważań, kluczowym problemem w niniejszym artykule jest element prospołeczności podmiotów gospodarczych odpowiadających na wspomniane konflikty i napięcia gospodarcze. W literaturze odnosimy się obecnie do takich pojęć, jak ekonomia społeczna, społeczna gospodarka rynkowa, przedsiębiorstwa społeczne, społeczna odpowiedzialność biznesu, ekonomia wartości, ekonomia współdzielenia. Wszystkie te pojęcia i zagadnienia mają wspólny mianownik, mianowicie akcentują podmiotowość człowieka jako uczestnika procesów społeczno-gospodarczych. Na przestrzeni lat perspektywa nauki ekonomicznej stale się zmieniała. Mowa tu o zmianach w głównych założeniach ekonomii, umiejscowienia w jej analizach problemu produkcji, konsumpcji, inwestycji, podmiotów gospodarujących, a także znaczenia uwarunkowań otoczenia gospodarczego i umiejscowienia społecznych elementów i interpretacji zjawisk ekonomicznych. 
Odnosząc się krótko do historycznych zmian w założeniach ekonomii, należy zauważyć, że w epoce merkantylizmu celem działalności gospodarczej była produkcja. Merkantyliści akcentowali powiększanie bogactwa narodów przez eksport w wymianie handlowej. A. Smith - przedstawiciel szkoły klasycznej analizował w głównej mierze wzrost gospodarczy i rynki konkurencyjne. D. Ricardo w znacznej części swoich analiz zajmował się problemem podziału dochodu. Już za czasów J.S. Milla, w II poł. XIX w., w epoce rozwoju humanistyki zaznacza się rozróżnienie na ekonomię pozytywną i normatywną. Z kolei K. Marks zwracał uwagę na centralizację kapitału w ręku coraz to mniejszej liczby osób. Twórcy ekonomii neoklasycznej W.S. Jevons, C. Menger, L. Warla, opierali się na analizie marginalnej w teorii popytu i rozwijali zagadnienie użyteczności krańcowej. Natomiast już A. Marshall starał się połączyć metody matematyczne z określonym kontekstem historycznym, aby stworzyć narzędzie badawcze przynoszące użyteczność w zmieniających się czasach. Twierdził, że również jego rozwiązania staną się nieaktualne, ponieważ powstają nowe teorie adaptujące się do zmian społeczno-gospodarczych (Landreth, Colander , 2005: 310). Kolejnym etapem w rozwoju założeń ekonomii była szkoła instytucjonalna i heterodoksyjna krytyka ekonomii neoklasycznej, która interpretuje zjawiska gospodarcze w wielu aspektach (społecznych, politycznych, psychologicznych, historycznych itp.). Jej przedstawicielami są m.in. J. Schumpeter, M. Kalecki, F.A. Hayek, L. Mises i J.K. Galbraith.

W przedstawionej analizie widoczne jest, iż im bliżej czasów współczesnych, tym bardziej doceniany jest element podmiotowości człowieka i uwzględniania czynników pozaekonomicznych wpływających na funkcjonowanie jednostek gospodarczych. Jest to tak znaczące, iż wpływa na zmiany paradygmatu w naukach ekonomiczno-społecznych.

Jak zaznacza się w literaturze naukowej, paradygmatu danej dziedziny nie podważa się, dopóki właściwie określa, definiuje ten aspekt rzeczywistości, którego dotyczy. Stawiane są zatem pytania o to, w jakim stopniu ekonomia jako nauka społeczna właściwie przedstawia działalność człowieka w ramach zjawisk społeczno-gospodarczych oraz w jakim stopniu współczesne teorie ekonomii właściwie określają świat i rzeczywistość społeczno-gospodarczą (Filek, 2017: 48). Z całą pewnością należy zaznaczyć wprowadzenie praw człowieka i obywatela w obszar życia gospodarczego. Wyjaśnić to można na przykładzie różnic, które warunkują działalność przedsiębiorstw komercyjnych i tzw. przedsiębiorstw społecznych (czyli nastawionych na realizację celu społecznego) (Brdulak, Florczak, 2016: 29):

1. Motywy powstania: Przedsiębiorstwo społeczne cechuje się tym, iż powoływane zostaje z powodu i dla celów społecznych, do realizowania zmiany społeczno-ekonomicznej otoczenia. W przypadku przedsiębiorstw komercyjnych motywem powstania są względy maksymalizacji zysku i ekspansji rynkowych.

2. Misja: Dla przedsiębiorstw społecznych realizowanie celów społecznych jest jednoznacznie połączone z misją przedsiębiorstwa, a zysk jest narzędziem do realizacji tych celów. Społeczna odpowiedzialność przedsiębiorstw komercyjnych jest nierzadko działaniem akcesoryjnym, mającym na celu również względy marketingowe prowadzące do maksymalizacji zysków finansowych przedsiębiorstwa.

3. Podwójny rachunek wartości ekonomiczno-społecznej: Przedsiębiorstwa społeczne dążą do realizacji zysków mających parametry społecznej użyteczności i społecznego oddziaływania pośredniego i bezpośredniego. 
4. Ostateczny cel: Cele w przypadku przedsiębiorstw społecznych i przedsiębiorstw komercyjnych różnią się akcentami. Dla przedsiębiorstw społecznych priorytetem jest cel społeczny, przy pomocniczym procesie realizacji zysków. Przedsiębiorstwa komercyjne dążą do realizacji celów finansowych, uzupełniając ten cel względami społecznymi.

Działalność przedsiębiorstw jest jednym z przejawów prospołeczności w gospodarce. W kontekście szerszego spektrum prospołeczności we współczesnej praktyce ekonomicznej akcentuje się również rolę społecznej odpowiedzialności biznesu. Ewolucja społecznej odpowiedzialności biznesu polega na tym, że z jednej strony odnosi się do działalności przedsiębiorstwa indywidualnie ujętej na podstawie jego strategii, struktury klientów, interesariuszy, branży, w której funkcjonuje, ale z drugiej strony obserwujemy szersze odwoływanie się do ogólnego poziomu rozwoju społeczno-gospodarczego w ramach założeń koncepcji zrównoważonego rozwoju (Brdulak, Florczak, 2016: 29).

W dyskusji na temat paradygmatu ważna jest koncepcja Kuhna, dla którego zmiana paradygmatu wiąże się nie tylko z jakościową zmianą w dziedzinach nauki, ale także z wzbogaceniem teorii o nowe fakty i nowe ich ujęcie, czyli teorie. Zmiana paradygmatu dotyczy więc właściwego, aktualnego dostosowania nauki do opisywanej rzeczywistości. Obserwowanie współczesnej prospołeczności w gospodarce polega na dostrzeganiu zmian przede wszystkim jakościowych i świadomościowych w prowadzeniu działalności gospodarczej. Już nie tylko jest to działalność nastawiona na maksymalizację zysków i uwzględnianie jedynie ekonomicznych czynników kształtujących rynek. Tak jak kluczową koncepcją liberalizmu ekonomicznego jest indywidualizm metodologiczny, tak społecznotwórcza rola podmiotów gospodarczych polega nie tylko na produkcji dóbr i usług, ale też na pewnym udziale w rozwiązywaniu problemów społecznych.

Ważne stanowisko w tej sprawie zajmuje G. Kołodko, którego zdaniem „Ekonomia w dotychczasowej ortodoksyjnej postaci (ekonomia głównego nurtu) wyczerpuje swoje możliwości poznawcze i aplikacyjne. Ekonomia w jej ujęciu poznawczym w zasadzie dotyczy przeszłości, natomiast problemy, które ma rozwiązać, rodzą się współcześnie i oddziaują na przyszłość” (Kołodko, 2017: 59). Szczególnie istotne są tu dwie kwestie. Po pierwsze, w tzw. starej ekonomii czynniki pozaekonomiczne nie były ujmowane jako znaczące dla naukowych założeń i nie wchodziły w zakres analiz metodologicznych. Po drugie, starą ekonomię tworzyły gospodarki narodowe - systemy gospodarcze w dużym stopniu odrębne i niezależne od siebie, nieuwzględniające globalizacyjnych zależności i uwarunkowań społeczno-gospodarczych, które globalizacja implikuje. Dlatego duże znaczenie ma bieżąca analiza praktyki gospodarczej w celu dostosowania narzędzi i założeń badawczych do współczesnych trendów i zachowań w środowisku społeczno-gospodarczym. Z tego też względu założenia ekonomii w rozumieniu nowego pragmatyzmu powinny dążyć do tworzenia struktury społeczno-gospodarczej opartej na zasadach zrównoważonego rozwoju, w ujęciu ekonomicznym, społecznym i ekologicznym. W tym znaczeniu ekonomia staje się nauką różnokierunkową i wielopłaszczyznową.

Ciekawy kierunek interpretacji współczesnych przemian i kształtowania się nowego paradygmatu wprowadziła analiza tzw. megatrendów. Za twórcę tego pojęcia uznaje się J. Naisbitta, który w publikacji z 1982 r. określił 10 zjawisk oraz procesów społecznych i gospodarczych zachodzących w amerykańskiej gospodarce, a będących początkiem istotnych zmian w życiu społeczno-gospodarczym: 
- od społeczeństwa przemysłowego do społeczeństwa informacyjnego; przemiany te wiązały się z aktywnym uczestnictwem poszczególnych jednostek społeczeństwa, a także z oparciem rozwoju na wiedzy i innowacji,

- od technologii siłowej do ultratechnologii/ultrastyku, gdzie istotnego znaczenia nabierają reakcje i relacje społeczne,

- od gospodarki narodowej do gospodarki globalnej, czyli gospodarki powiązanej z innymi państwami ekonomicznie, a także społecznie i kulturowo,

- od myślenia krótkofalowego do długookresowego, a także myślenia wielopłaszczyznowego,

- od centralizacji do decentralizacji, a także oddolnej społecznej organizacji,

- od pomocy zinstytucjonalizowanej do samopomocy - jest to związane również z rozwojem przedsiębiorczości społecznej,

- od demokracji przedstawicielskiej do uczestniczącej i zwiększonej bezpośredniej partycypacji społeczeństwa obywatelskiego,

- od hierarchii do sieci, zarówno w życiu gospodarczym, jak i społecznym,

- z Północy na Południe, co związane jest z otwieraniem się na dotychczas separowane obszary na świecie,

- od schematu „albo-albo” do wielokrotnego wyboru, i łączenia wielu celów i motywów (Naisbitt, 1982).

Megatrendy, zwane też trendami globalnymi, ogólnoświatowymi czy cywilizacyjnymi, wpływają na zmiany jakościowe w wymiarze ekonomicznym, społecznym, socjologicznym lub strukturalnym. Ponadto zaobserwować można zmiany w specyfice aktywności podmiotów gospodarujących (zarówno przedsiębiorstw, jak i gospodarstw domowych i konsumentów). W związku z tym niezaprzeczalny jest fakt, że współczesna metodologia badawcza ekonomii powinna $\mathrm{z}$ jednej strony uwzględnić te uwarunkowania, a z drugiej strony tak zmodyfikować narzędzia i metody badawcze, aby właściwie rozpoznawały zależności przyczynowo-skutkowe w dzisiejszej przestrzeni społeczno-gospodarczej. Niewątpliwe znaczenie ma tutaj rozwój nurtu ekonomii instytucjonalnej. W opinii instytucjonalistów, z T. Veblenem na czele, aktywność jednostek - w ujęciu ekonomicznym - jest ściśle powiązane z uwarunkowaniami społecznymi i kulturowymi. Nawet sformalizowane zasady i działania, czy legislacyjne reguły funkcjonowania, mają swoje źródło w otoczeniu społecznym, a normy społeczne, wartości i zwyczaje wpływają na sposób kształtowania kultury organizacji. W związku z tym instytucje społeczne, czyli sposoby, mechanizmy myślowe czy schematy określania zjawisk, które kierują ludzkim życiem, pochodzą z przeszłości. Tutaj pojawia się kolejne wyzwanie dla stworzenia właściwego aparatu zależności między praktyką gospodarczą a teoriami ekonomii odnoszącymi się do jej funkcjonowania - zarówno w aspekcie pozytywnym, jak i normatywnym. Zdaniem D.C. Northa, „wzrost idący w parze z rozwojem jest możliwy tylko wówczas, gdy społeczeństwo posiada zdolność do tworzenia norm współpracy i prezentuje postawy kreatywności" (North, 1997: 6).

Jak podaje literatura przedmiotu, powodem wyłaniania się instytucji jest określony sposób reagowania jednostek i społeczeństw na zmieniające się uwarunkowania życia społeczno-gospodarczego (Miszewski , 2018: 85). Dlatego ważnym elementem faz rozwoju i zmian systemu instytucjonalnego jest „dojrzewanie i starzenie się” instytucji. Proces ten ma obiektywny, oddolny, naturalny wymiar. W tym kontekście warto zwrócić uwagę na zmiany o charakterze społecznym, które mają wpływ na działalność gospodarczą 
- dotyczy to prospołecznej roli państwa, prospołecznych motywów aktywności gospodarczej przedsiębiorstw i prospołecznej postawy gospodarstw domowych i konsumentów.

Zmiana ujęcia prospołeczności dotyczy wielu wymiarów gospodarowania. I tak np. zmiana podejścia środowiska i otoczenia społecznego do kwestii społecznej odpowiedzialności biznesu doprowadziła do przekierowania debaty z dyskusji na temat celowości idei CSR, na kwestie rzeczywistych zachowań i aktywności jednostek gospodarczych. W konsekwencji w miejsce doktryny społecznej odpowiedzialności biznesu pojawiła się koncepcja społecznego reagowania (corporate social responsiveness - CRS2), a następnie koncepcja społecznego wkładu (corporate social performance - CSR3). W wymiarze teorii ekonomii odnieść się można do ekonomii behawioralnej i jej definicji zaproponowanej przez M. Nogę: „Ekonomia behawioralna wszystkie prawa i kategorie ekonomii głównego nurtu analizuje przez filtr wyników badań (praw) socjologii i psychologii, co powoduje, że odkrywane są nowe prawa ekonomiczne lub/i modyfikowane są «stare» prawa ekonomiczne. W ten sposób powstaje nowy zmodyfikowany paradygmat ekonomii głównego nurtu” (Noga, 2017: 48). Podsumowując, człowiek i jednostki gospodarcze w swojej aktywności zdeterminowane są istniejącymi w społeczeństwie i gospodarce: kulturą, instytucjami, nieformalnymi i formalnymi ograniczeniami.

Przedsiębiorstwo społeczne i społeczna gospodarka rynkowa jako kierunek zmian w postrzeganiu rynku i działalności gospodarczej

Na zmiany w paradygmacie ekonomii wpływają bieżąca praktyka gospodarcza, a także uwarunkowania i bodźce, które oddziałują na kierunek jej rozwoju. Autorzy w tym zakresie zwracają uwagę na zjawisko występowania prospołeczności w postaci przedsiębiorstwa społecznego i gospodarki społecznej. Wzrost roli prospołeczności w gospodarce osłabi występujące konflikty życia społeczno-gospodarczego, może przyczynić się do redukcji napięć kapitalistycznych stosunków produkcji i zarazem do systematycznej redukcji kosztów globalnej gospodarki oraz życia społecznego.

Europejską definicję podaje J. Defourny, dla którego przedsiębiorstwo społeczne to działalność gospodarcza, która wyznacza sobie cele ściśle społeczne i która inwestuje ponownie nadwyżki zależnie od tych celów w działalności lub we wspólnotę, zamiast kierować się potrzebą osiągania maksymalnego zysku na rzecz akcjonariuszy lub właścicieli (Defourny, 2008: 13). Koncepcja przedsiębiorstwa społecznego w tym ujęciu rozpatrywana jest $\mathrm{z}$ punktu widzenia trzech biegunów, tj. państwa, rynku i społeczeństwa obywatelskiego, w którym zachodzą interakcje prowadzące do utworzenia przedsiębiorstwa społecznego generujące relacje „wzajemności” (rycina 1).

Zmiany paradygmatu w interpretacji ekonomii dotyczą zarówno celów funkcjonowania podmiotów gospodarczych, jak również systemu relacji w budowaniu przestrzeni rynkowej. Nietrwałość neoliberalnego paradygmatu dwubiegunowego (rynek-państwo) uformowała optykę, gdzie aktorami jest tylko rynek i państwo (rycina 1). Jak słusznie zauważa C. Borzaga, rynkowi powierzona była rola produkcji i alokacji dóbr prywatnych, a następnie dystrybucji zasobów zgodnie z zasadą wkładu indywidualnego, [...] a państwo było odpowiedzialne za produkcję dóbr publicznych i dóbr, których nie mógł wytworzyć rynek, z czego często jak wiemy nie mogło się wywiązać, [...] dlatego też potrzebny jest nowy paradygmat, który umiejscowi obywatelskie działania na rzecz dobra ogólnego obok działań państwa, rynku i rodziny (Borzaga, 2007: 81-92). W zmianie paradygmatu 
Rycina 1. Miejsce przedsiębiorstw społecznych w gospodarce

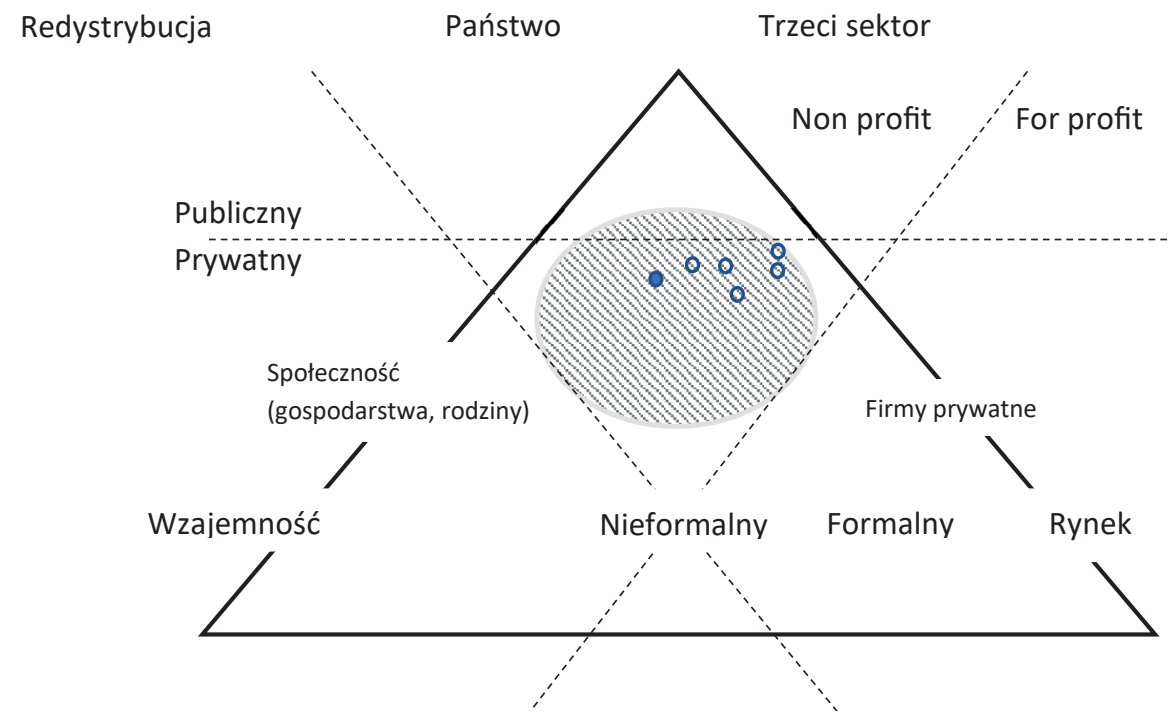

Źródło: Defourny (2008: 85)

może pomóc kluczowy motyw działania przedsiębiorczego, zwłaszcza przedsiębiorczości społecznej, którym jest misja. Jak potwierdza P. Drucker: „Organizacje istnieją dzięki swej misji i dla niej. Istnieją po to, by zmienić coś w społeczeństwie, w życiu jednostki. Istnieją, bo istnieje ich misja" (Drucker, 1995: 59). Stąd w polskiej literaturze definicja przedsiębiorstwa społecznego jako organizacji lub innego przedsięwzięcia, dążących do realizacji misji społecznej przez działanie przedsiębiorcze, zorientowane na wypracowanie własnego dochodu (Herbst, 2008: 9-10).

Przedsiębiorstwo społeczne usytuowane jest w ordoliberalnym ładzie jako „subład” - ekonomii (gospodarki) społecznej. W tym miejscu przedsiębiorstwo społeczne według J. Hausnera, N. Laurisza i S. Mazura jest kluczowym ogniwem ekonomii społecznej, ponieważ jego funkcją nie jest tylko wytwarzanie określonych dóbr i usług, ale też mobilizacja kapitału społecznego, generowanie innowacyjności oraz poszerzanie rynku przez włączanie do uczestnictwa w nim osób dotychczas wykluczonych, Mimo że jest ono częścią gospodarki rynkowej, to jednak lokuje swoją misję i cele poza rynkiem (Florczak, 2016: 27-38; Hausner, Laurisz, Mazur, 2007: 9). Cel przedsiębiorstwa rynkowego również leży poza rynkiem, tj. poza obrębem swojego biznesu. Jak podaje Drucker: musi on leżeć w samym społeczeństwie, skoro przedsiębiorstwo jest organem społeczeństwa. Stąd jedyna poprawna definicja celu biznesu to „tworzenie klienteli”. Umiejscowienie przedsiębiorstwa społecznego i zależności pomiędzy społeczeństwem obywatelskim, ekonomią społeczną a gospodarką rynkową obrazuje rycina 1, gdzie istotne jest zastrzeżenie, że nie można utożsamiać podmiotów ekonomii społecznej z organizacjami pozarządowymi. Trzeci sektor obejmujący tu zasięgiem organizacje pozarządowe jest obszarem konwergencji koncepcji sektora niedochodowego (non profit) i gospodarki społecznej. Gospodarka społeczna stanowi nowe narzędzie rozwoju społeczno-gospodarczego na szczeblu lokalnym, komplementarne wobec sektora prywatnego i publicznego. Instytucje 
gospodarki społecznej, m.in. organizacje obywatelskie i spółdzielczość, przyczyniają się do tworzenia nowych usług i nowych miejsc pracy w ramach przedsięwzięć łączących w sobie ekonomiczne i społeczne aspekty aktywności obywatelskiej.

$\mathrm{W}$ ostatnich latach obserwujemy również zmianę w sposobie postrzegania gospodarki rynkowej. Zmiana ta jest spowodowana nowymi rozwiązaniami instytucjonalnymi w powoływaniu podmiotów gospodarki społecznej. W przypadku przedsiębiorstw społecznych i podmiotów gospodarki rynkowej obserwujemy znaczną różnorodność form odnoszących się do aspektów organizacyjno-prawnych (i zakresu ich działalności), uwarunkowaną przyjętymi rozwiązaniami prawnymi, sytuacją społeczno-gospodarczą, jak również tradycją. Dlatego tak ważną rolę odrywa identyfikacja w praktyce gospodarczej podmiotów realizujących cele społeczne i funkcjonujących w oparciu o pozarynkowe uwarunkowania.

\section{Zakończenie}

Artykuł miał na celu zdiagnozowanie problemu zmian w naukach ekonomicznych, które są współczesną odpowiedzią na problemy życia społeczno-gospodarczego. Biorąc pod uwagę skomplikowanie zjawisk gospodarczych i ich uwarunkowań, autorzy stawiają tezę, że ekonomia humanizuje się i poszukuje nowego ładu w kreowaniu rozwoju społeczno-gospodarczego. Przejawia się to zarówno w specyfice uwarunkowań współczesnego kapitalizmu, jak i w postępujących przejawach prospołeczności w naukach ekonomicznych oraz w praktyce gospodarczej. Niezaprzeczalny jest fakt podążania we współczesnych naukach ekonomicznych w kierunku wartości jakościowych i rozwiązywania problemów społecznych zarówno w przestrzeni makro-, jak i mikroekonomicznej. W kontekście takich potrzeb została zaproponowania formuła przedsiębiorstwa społecznego i gospodarki społecznej jako zjawisk gospodarczych, które mogą wpłynąć zarówno na praktykę gospodarczą, jak i na kierunki rozwoju myśli ekonomicznej. Poszukiwanie prospołeczności w ekonomii wymaga przeprowadzania badań w skali makro- i mikroekonomicznej, a także w różnych obszarach życia gospodarczego. Niniejszy artykuł nie wyczerpuje w pełni wyodrębniającego się tematu prospołeczności, dlatego autorzy zamierzają kontynuować rozważania naukowe, badania empiryczne i obserwację praktyki gospodarczej przedstawionej problematyki. Wyrażają jednocześnie nadzieję, że postawiona na wstępie teza została udowodniona, a ranga sygnalizowanego problemu humanizacji ekonomii stanowić będzie przesłankę dalszej dyskusji naukowej.

\section{Literatura}

References

Borzaga, C. (2007). Nowe trendy w partycypacji obywatelskiej: rosnąca rola zachowań społecznie odpowiedzialnych w konsumpcji, oszczędzaniu i produkcji. Zeszyty Gospodarki Społecznej, 2, 79-100.

Brdulak, J., Florczak, E. (2016). Uwarunkowania działalności przedsiębiorstw społecznych w Polsce. Warszawa: Oficyna Uczelni Łazarskiego w Warszawie.

Brdulak, J., Florczak, E., Gardziński, T. (2019a). The Socialization of Capitalism through Social Enterprises. International Journal of Small and Medium Enterprises and Business Sustainability, 2(4), 68-87. 
Brdulak, J., Florczak, E., Gardziński, T. (2019b). Uspołecznienie kapitalizmu w Europie ŚrodkowoWschodniej. Myśl Ekonomiczna i Polityczna, 1(64), 61-77.

Defourny, J. (2005). Przedsiębiorstwo społeczne w poszerzonej Europie: koncepcja i rzeczywistość. W: „Ekonomia społeczna” II Europejska Konferencja Ekonomii Społecznej, Kraków 2004: materiały (Ministerstwo Polityki Społecznej), Warszawa 2005, 43-65.

Defourny, J. (2006). Social Enterprises in Western Europe: Some Insights from the EMES Experience. UNDPEMES Regional Workshop on Social Enterprises in CEE and CIS. Brussels, December $11-12$.

Dirksen, U. (2018). Die Zukunft der Arbeit beginnt jetzt!. Friedrich-Ebert-Stiftung.

Drucker, P.F. (1994). Praktyka zarządzania. Warszawa: „Nowoczesność” Sp. z o.o.

Drucker, P.F. (1995). Zarzadzanie organizacja pozarządową. Teoria i praktyka. Fundusz Współpracy. Program Phare Dialog Społeczny - NGOs, Warszawa.

Filek, J. (2017). Czy koncepcja społecznej odpowiedzialności biznesu może być inspiracją dla nowego paradygmatu ekonomii?. W: E. Mączyńska, J. Sójka (red.), Etyka i ekonomia. W stronę nowego paradygmatu. Warszawa: PTE, 45-59.

Florczak, E. (2016). Nierówności społeczno-ekonomiczne a cele przedsiębiorstwa społecznego. Kwartalnik Nauk o Przedsiębiorstwie, 4, 27-38.

Hausner, J. (red.). (2008). Przedsiębiorstwa społeczne w Polsce. Teoria i praktyka, t. 4. Kraków: Uniwersytet Ekonomiczny w Krakowie.

Hausner, J., Laurisz, N., Mazur, S. (2007). Przedsiębiorstwo społeczne - konceptualizacja. W: J. Hausner (red.),Zarzadzanie podmiotami ekonomii społecznej, t. 2, Kraków: Małopolska Szkoła Administracji Publicznej Uniwersytetu Ekonomicznego w Krakowie.

Herbst, J. (2008). Wstęp - pole przedsiębiorczości społecznej. W: J. Dąbrowska (red.), Od trzeciego sektora do przedsiębiorczości społecznej - wyniki badań ekonomii społecznej w Polsce. Warszawa: Stowarzyszenie Klon/Jawor.

Kołodko, G. W. (2017). Nowy pragmatyzm i jego znaczenie dla uczciwego gospodarowania. W: E. Mączyńska, J. Sójka (red.), Etyka i ekonomia. W stronę nowego paradygmatu. Warszawa: PTE.

Kuciński, K. (red.). (2015). Geografia ekonomiczna. Warszawa: Oficyna Wolters Kluwer business.

Landreth, H., Colander, D.C. (2021). Historia myśli ekonomicznej. Warszawa: PWE.

Leś, E., Ołdak, M. (red.). (2007). Przedsiębiorstwo społeczne w rozwoju lokalnym. Zeszyty Gospodarki Społecznej, 2.

Leśniewski, M.A. (2015). Konkurencyjność miękka przedsiębiorstw. Warszawa: Difin.

Liberska, B. (red.). (2002). Globalizacja. Mechanizmy i wyzwania. Warszawa: PWE.

Miroński, J. (2013). Homo administratus, czyli człowiek w naukach o zarządzaniu. Warszawa: SGH.

Miszewski, M. (2018). Zmiana instytucjonalna a współczesne państwo. W: A. Ząbkowicz, M. Miszewski, P. Chmielnicki, S. Czech (red.), Zrozumieć kapitalizm. Podejście ewolucyjno-instytucjonalne. Sosnowiec: Oficyna Wydawnicza „Humanitas”.

Naisbitt, J. (1982). Megatrends. Ten New Directions Transforming Our Lives. New York.

Noga, M. (2017). Neuroekonomia a ekonomia głównego nurtu. Warszawa: Wydawnictwo CeDeWu.

North, D.C. (1997). Proloque. W: J.N. Drobak, J.V. Nye, The Frontiers of the New Institutional Economics. San Diego.

Palley, T.I. (2012). From Financial Crisis to Stagnation. Cambridge: Cambridge University.

Piketty, T. (2015). Kapitat w XXI wieku. Warszawa: Wydawnictwo Krytyki Politycznej.

Wrenn, M.V. (2018). Absorpcja nadwyżki i marnotrawstwo w neoliberalnym kapitalizmie monopolistycznym. W: G. Konat, P. Wielgosz (red.), Realny kapitalizm. Wokót teorii kapitału monopolistycznego. Warszawa: IW Książka i Prasa, 147-174.

Jacek Brdulak, dr hab., prof. Szkoły Głównej Handlowej w Warszawie, pracownik Kolegium Nauk o Przedsiębiorstwie. Zainteresowania naukowe: ekonomika transportu, rozwój przestrzenny infrastruktury technicznej gospodarki narodowej, gospodarka społeczna ze szczególnym uwzględnieniem roli przedsiębiorstw społecznych. 
Jacek Brdulak, professor at the SGH Warsaw School of Economics in the Collegium of Business Administration. His research interests include: economics of transport, spatial development of technical infrastructure of national economy, socio-economy with particular emphasis on the role of social enterprises.

ORCID: https://orcid.org/0000-0001-7881-1303

\section{Adres/Address:}

Szkoła Główna Handlowa w Warszawie

Katedra Geografii Ekonomicznej

ul. Rakowiecka 24, budynek A

02-521 Warszawa, Poland

e-mail: jacek.brdulak@sgh.waw.pl

Ewelina Florczak, dr, wykładowca Uczelni Łazarskiego w Warszawie. Zainteresowania naukowe: polityka społeczno-gospodarcza, społeczna gospodarka rynkowa, przedsiębiorczość społeczna, zarządzanie projektami, zarządzanie jakością.

Ewelina Florczak, PhD, lecturer at the Lazarski University in Warsaw. Her research interests include: socio-economic policy, social market economy, social entrepreneurship, project management, quality management.

ORCID: https://orcid.org/0000-0002-5958-7163

\section{Adres/Address:}

Wydział Ekonomii i Zarządzania

Katedra Zarządzania i Marketingu

ul Świeradowska 43

02-662 Warszawa, Poland

e-mail: ewelina.florczak@gmail.com

Tomasz Gardziński, mgr, wykładowca akademicki Uczelni Łazarskiego w Warszawie. Zainteresowania naukowe: społeczna gospodarka rynkowa, przedsiębiorczość społeczna. Menadżer sprzedaży w sektorze IT/Telco.

Tomasz Gardziński, MA, lecturer at the Lazarski University in Warsaw. His research interests include: social market economy, social entrepreneurship. He is a sales manager in IT/Telecommunications industry.

ORCID: https://orcid.org/0000-0001-8491-187X

\section{Adres/Address:}

Wydział Ekonomii i Zarządzania

Katedra Zarządzania i Marketingu

ul Świeradowska 43

02-662 Warszawa, Poland

e-mail: tg.gardek@gmail.com 